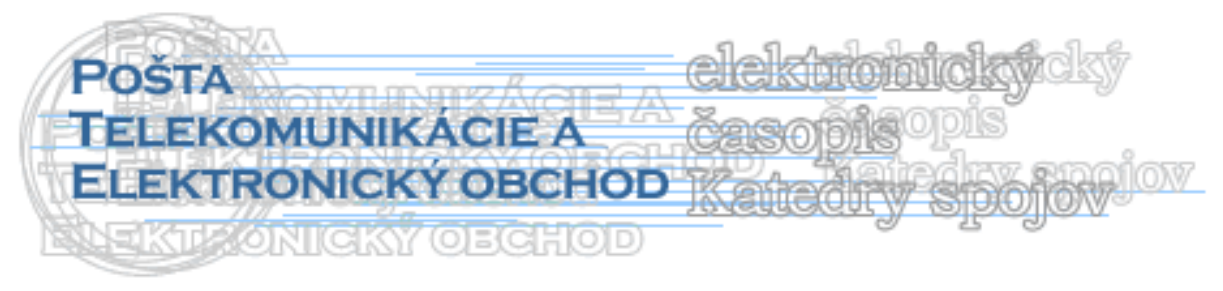

\title{
DIGITÁLNE ZRUČNOSTI OBYVATELOV ŽILINSKÉHO SAMOSPRÁVNEHO KRAJA
}

\author{
Matej Krejnus, Katarína Repková Štofková
}

\begin{abstract}
Slovakia has lot of obstacles that must solve little by little. This article is looked into a topic about digital skills that are essential for many enterprises and a government. The Slovakia needs to think up a good strategy to reach better outcomes the area of the digitalisation and digital skills of them civil in all of the segments of the people. Therefore, the aim of the article is to point out the digital skill people in Slovakia. People were stratified into groups, so I was able to identify the digital skills people in different areas. The survey was realized in 2020 year and I realized analysis of the DESI index in the area of the human capital.
\end{abstract}

Keywords: e-Government, digital skills, DESI index.

\section{Úvod}

V aktuálnej situácii, v ktorej sa svet nachádza sa kladie doraz na digitálne aktíva pre naše hospodárstvo. Dôraz je kladený na vysoko rýchlostné siete a prepojitel'nost', super počítače, dáta a umelú inteligenciu, ako aj na základné a pokročilé digitálne zručnosti, ktoré podporujú hospodárstvo štátov a rozvíjajú spoločnost'. Príspevok identifikuje a stratifikuje digitálne zručnosti u vybraných vekových kategórií aj na základe veku. Tiež poskytuje informácie o digitálnych zručnosti na základe Indexu digitálnej ekonomiky a spoločnosti (DESI). Členské štáty zaviedli konkrétne opatrenia na zmiernenie vplyvu pandémie. Digitálne technológie budú zohrávat' kl’účovú úlohu aj pri oživení svetovej ekonomiky. Európska rada a Komisia sa zaviazali spojit' podporu oživenia s paralelným prechodom na klimaticky neutrálnu a odolnú digitálnu transformáciu. V rámci, ktorý EÚ vytvorila sú na dosiahnutie dlhodobého oživenia ekonomiky dôležité zavedenia sietí $5 \mathrm{G}$ a sietí s vel'mi vysokou kapacitou (VHCN), digitálne zručnosti, digitalizácia podnikov a verejnej správy. Pomocou indexu DESI sa monitoruje pokrok v týchto oblastiach v každom členskom štáte. [1]

Digitálne technológie zohrávajú úlohu aj počas pandémie COVID-19 a tiež podpore ožívanie hospodárstva vo všetkých členských štátov EÚ vrátane Slovenska. Súčasná kríza má vplyv na spoločenské ukazovatele týkajúce sa využívania internetových služieb občanmi. Článok interpretuje zistenia z reportu DESI 2020 a výsledky indexu z oblasti l'udských zdrojov od roku 2018 do 2020.[1] Prieskumy boli realizované aj vo vybraných regiónoch. [2]

Zlepšovanie digitálnych zručností patrí medzi priority Stratégie digitálnej transformácie Slovenska 2030 [3] a súvisiaceho akčného plánu na roky 2019 - 2022 [4]. Ciel'om akčného plánu je vzdelávací systém prispôsobit' a zamerat' sa na digitálne zručnosti, ktoré sú požadované v zamestnaní. V stratégii sa uvádza potreba rozvíjania, tzv. soft skills produktívnych osobných vlastnosti, ktoré charakterizujú vzt'ah v sociálnom prostredí a kompetencií pre zapájanie sa do fungovania digitálnej spoločnosti. Slovenské podnikatel'ské sektory si vyžadujú reformy vzdelávacieho systému, aby sa zmenšil nesúlad medzi zručnost’ami, ktoré absolventi nadobúdajú vo vzdelávacích inštitúciách a zručnost’ami, ktoré vyžadujú zamestnávatelia. [5-6] V indexe DESI 2020 a oblasti l’udského kapitálu je 
Slovensko na 20. pozícii spomedzi všetkých krajín 27 EÚ. Výsledne hodnoty sú uvedené v tabul'ke 1. [1]

Tabul'ka 1. Hodnota DESI 2020 v oblasti l'udské zdroje

\begin{tabular}{|c|c|c|c|}
\hline \multirow{2}{*}{ L'udský kapitál } & \multicolumn{2}{|c|}{ Slovensko } & EÚ \\
\cline { 2 - 4 } & Poradie & skóre & 49,3 \\
\hline DESI 2020 & 20 & 41,8 & 47,9 \\
\hline DESI 2019 & 18 & 44,2 & 47,6 \\
\hline
\end{tabular}

Zdroj: europa.eu, [online]. [cit. 2021-8-10]. Dostupné na internete: < https://nk.sk/sab7 > vlastné spracovanie.

Skóre ako podiel občanov, ktorí uvádzajú, že majú digitálne zručnosti sa znížilo. Podiel občanov s viac ako základnými digitálnymi zručnost’ami je $27 \%$, čo je najlepšie skóre v regióne Vyšehradskej štvorky, ale stále nedosahuje priemer EÚ 33 \% - tabul'ka 2. [1]

Tabul'ka 2. Digitálne zručnosti obyvatel'ov na základe DESI 2020

\begin{tabular}{|c|c|c|c|c|}
\hline \multirow{2}{*}{\begin{tabular}{c} 
Digitálne zručnosti \\
\cline { 2 - 5 }
\end{tabular}} & DESI 2018 v [\%] & DESI 2019 v [\%] & DESI 2020 v [\%] & $\begin{array}{c}\text { EÚ DESI } \\
\mathbf{2 0 2 0} \\
\text { hodnota }\end{array}$ \\
\hline $\begin{array}{c}\text { Aspoň základné digitálne } \\
\text { zručnosti } \\
{[\%] \text { obyvatel'ov }}\end{array}$ & 59 & 59 & 54 & 58 \\
\hline $\begin{array}{c}\text { Viac ako základné digitálne } \\
\text { zručnosti } \\
{[\%] \text { obyvatel'ov }}\end{array}$ & 33 & 33 & 27 & 33 \\
\hline $\begin{array}{c}\text { Aspoň základné softvérové } \\
\text { zručnosti } \\
{[\%] \text { obyvatel'ov }}\end{array}$ & 63 & 63 & 56 & 61 \\
\hline
\end{tabular}

Zdroj: europa.eu, [online]. [cit. 2021-8-10]. Dostupné na internete: < https://lnk.sk/sab7 > vlastné spracovanie.

Z uvedenej tabul'ky môžeme vidiet', že zo stagnujúceho stavu v rokoch 2018 a 2019. V roku 2020 došlo k poklesu o $5 \%$ obyvatel'ov, ,aspoň zo základnými digitálnymi zručnost'ami“. Z toho vyplýva, že Slovensko sa dostalo v roku 2020 pod priemer EÚ. Identický stav nastal v roku 2020 aj pri oblasti „viac ako základné digitálne zručnosti“, kde nastalo zníženie o $6 \%$ obyvatel'ov. Aspoň základné softvérové zručnosti mali v roku 201863 \% obyvatel'ov, avšak v roku 2020 je ich $56 \%$ obyvatel'ov, nastal pokles o 7 \% bodov. Aj v oblasti l'udských zdrojov sa Slovensko dostalo pod priemer EÚ.

V oblasti l'udského kapitálu je Slovensko na 20. mieste zo všetkých krajín EÚ. Skóre, ktoré môžeme interpretovat' ako podiel občanov, ktorí uvádzajú, že majú digitálne zručnosti, sa znížilo. Podiel občanov s viac ako základnými digitálnymi zručnost’ami je $27 \%$, čo predstavuje najlepšie skóre $\mathrm{v}$ regióne Vyšehradskej štvorky, avšak skoré Slovenska nedosahuje priemer EÚ $33 \%$. Podiel odborníkov v oblasti IKT z celkového počtu zamestnancov narástol na 3,2 \%, ale stále nedosahuje priemer EÚ, ktorý je 3,9\%. V odbore IKT je podiel absolventov na úrovni 3,3\%, ale stále nedosahuje priemer EÚ, ktorý je 3,6\%. Nasledujúcim problémom je nízka úroveň digitálnej gramotnosti u mladých l'udí. $Z$ výsledkov a hodnotenia štátnej školskej Slovenskej inšpekcie až $45 \%$ škôl nemá ani jedného kvalifikovaného učitel'a IT [6].

Z prieskumu o IKT vo vzdelávaní [7] má len $17 \%$ slovenských základných škôl dobré digitálne vybavenie a pripojenie (priemer EÚ: $35 \%$ ). Mládež a deti intenzívne používajú digitálne nástroje a internet na zábavu, v správe indexu DESI [1] sa uvádza, že len štyria z desiatich sú schopní vytvárat' prezentácie, grafy alebo pracovat's tabul'kami. Situácia je obzvlášt' vážna $v$ rodinách na nižššej sociálno-ekonomickej úrovni. Na Slovensku sa 
uskutočňuje viacero iniciatív, a to napríklad IT Fitness test [8] alebo IT Akadémia [9]. Ciel'om týchto projektov je zlepšovanie a zvýšenie úrovne digitálnych zručností žiakov a učitel'ov. Slovensko sa usiluje riešit' problémy v tejto oblasti pomocou Národného vzdelávacieho programu [10]. V tomto programe sa zdôrazňuje potreba zvýšit' mieru používania digitálnych technológií $\mathrm{v}$ triedach a zlepšovat' digitálne zručnosti žiakov aj učitel'ov.

Slovensko má aktívnu Národnú koalíciu pre digitálne zručnosti a povolania SR, ktorá úzko spolupracuje s vládou. [11] Slovensko sa pravidelne zapája do Európskeho týždňa programovania. Počet aktivít sa zvýšil o $8 \%$ v roku 2018, a to na počet 165 .

Slovensko v indexe DESI (oblasti l'udského kapitálu) už nedosahuje najlepšie výsledky spomedzi všetkých oblasti, ktoré sú prepojitel'nost', l'udský kapitál, využívanie internetových služieb, digitálne verejné služby. Skóre kleslo a nedosahuje priemer EÚ. Stratégia Slovenskej republiky pozostáva $\mathrm{z}$ reformy vzdelávania a prispôsobení technologickému vývoju a v lepšom vybavení žiakov zručnost’ami a kompetenciami na život a prácu $\mathrm{v}$ digitálnej ekonomike. Hlavnou výzvou bude premietnut' túto stratégiu do konkrétnych akcií, zabezpečit' financovanie a využit' súčasné iniciatívy, ako je IT Fitness test, na dosiahnutie zlepšovania a zvýšenia úrovne digitálnych zručností a vplyvu u väčšej časti obyvatel'stva.

\section{Ciel' a metodológia}

Ciel'om článku je poukázat' na digitálne zručnosti obyvatel'ov Žilinského samosprávneho kraja (ŽSK) v jednotlivých vybraných kategóriách ako sú vzdelanie, občiansky status a iné. Ciel'om je aj identifikovat' stav digitálnych zručnosti a zistit'; úroveň digitálnych zručnosti obyvatel’ov ŽSK. Primárny prieskum bol realizovaný elektronickým dopytovaním, ktorého sa zúčastnilo 296 respondentov. Stratifikácia respondentov bola realizovaná na základe identifikačných otázok, ktoré sú v łabul'ke 3 a 4 . Respondenti boli rozdelení na základe veku, ekonomického zaradenia a najvyššieho dosiahnutého vzdelania. Výsledky primárneho výskumu a odpovede od respondentov sú graficky a písomne interpretované a hodnoty sú uvádzané v percentách. Dopytovanie respondentov prebiehalo v časovom intervale od 10.02.2020 do 28.02.2020. Primárny výskum obsahuje zadefinovanie úrovne digitálnych zručnosti k využívaniu služieb e-Governmentu. Boli zadefinované 4 druhy úrovni digitálnych zručnosti, z ktorých si mohol respondent vybrat'. Úrovne digitálnych zručnosti sú nasledujúce.

- Nemám digitálne zručnosti - nedokážem komunikovat' prostredníctvom digitálnych technológií súradmi verejnej správy (výhradne osobný kontakt, nevyužívam počítač, internet a pod.),

- Používatel’ základného jazyka - som si vedomý(á), že pri styku s úradmi môžem využit' digitálne technológie, ale ich nevyužívam, s úradmi komunikujem osobne,

- Samostatný používatel' - som schopný(á) používat' niektoré funkcie online verejné služby (eznamka.sk, katasterportal.sk a iné),

- Skúsený používatel' - aktívne využívam viaceré online služieb verejnej správy (slovensko.sk, národný portál zdravia a iné).

Predmetom skúmania primárneho výskumu boli obyvatelia ŽSK. Pri výpočte bol použitý základný súbor vo vel'kosti: 690000 obyvatel'ov.[12] 
Variabilnost' základného súbor ,p“ predstavuje hodnotu 0,5. Interval spol’ahlivosti je $95 \%$ a maximálne prístupne rozpätie chyb „,“ predstavuje hodnotu 5,7 \%.

$\sigma=\sqrt{p *(1-p)}=\sqrt{0,5 *(1-0,5)}=0,5$

$n \geq t_{1-\frac{\alpha}{2}}^{2} * \frac{\sigma^{2}}{\Delta^{2}}=1,96^{2} * \frac{0,5^{2}}{0,057^{2}}=296$ respondetov

Skupina, ktorá ma najpočetnejšie zastúpenie v primárnom výskume sú zamestnanci vo vekovej kategórii od 20 do 29 rokov a od 30 do 39 rokov s vysokoškolským vzdelaním II. stupňa a so stredoškolským vzdelaním s maturitou pozri v tabul'ke 3 a 4.

Tabul'ka 3 Identifikačná tabul'ka respondentov

\begin{tabular}{|l|c|c|}
\hline Do ktorej vekovej kategórie patríte? & Počet respondentov & Počet spolu v (čísle) a (\%) \\
\hline do 19 & 19 & 296 \\
\hline do 20 do 29 & 79 & $100 \%$ \\
\hline do 30 do 39 & 75 & \\
\hline do 40 do 49 & 54 & \\
\hline do 50 do 59 & 43 & 26 \\
\hline do 60 a viac & 26 \\
\hline
\end{tabular}

Zdroj: vlastné spracovanie

Tabul'ka 4 Identifikačná tabul'ka respondentov

\begin{tabular}{|c|c|c|}
\hline Aké je Vaše ekonomické zaradenie? & Počet respondentov & Počet spolu v (čísle) a (\%) \\
\hline Zamestnaný & 147 & \multirow{6}{*}{$\begin{array}{c}296 \\
100 \%\end{array}$} \\
\hline Podnikatel' & 73 & \\
\hline Študent & 61 & \\
\hline Materská dovolenka & 7 & \\
\hline Dôchodca & 6 & \\
\hline Nezamestnaný & 2 & \\
\hline $\begin{array}{c}\text { Aké je Vaše najvyššie dosiahnuté } \\
\text { vzdelanie? }\end{array}$ & Počet respondentov & Počet spolu v (čísle) a (\%) \\
\hline Základná škola & 12 & \multirow{6}{*}{$\begin{array}{c}296 \\
100 \%\end{array}$} \\
\hline Stredná škola bez maturity - výučný list & 5 & \\
\hline Stredná škola s maturitou & 96 & \\
\hline Vysoká škola I. stupňa & 40 & \\
\hline Vysoká škola II. stupňa & 124 & \\
\hline Vysoká škola III. stupňa & 19 & \\
\hline
\end{tabular}




\section{Výsledky}

Z výsledkov primárneho prieskumu vyplýva, že znalost' pojmu e-Government je medzi respondentami výrazná, avšak nájdu sa aj skupiny obyvatel’ov, ktorí sa s týmto pojmom nestreli.

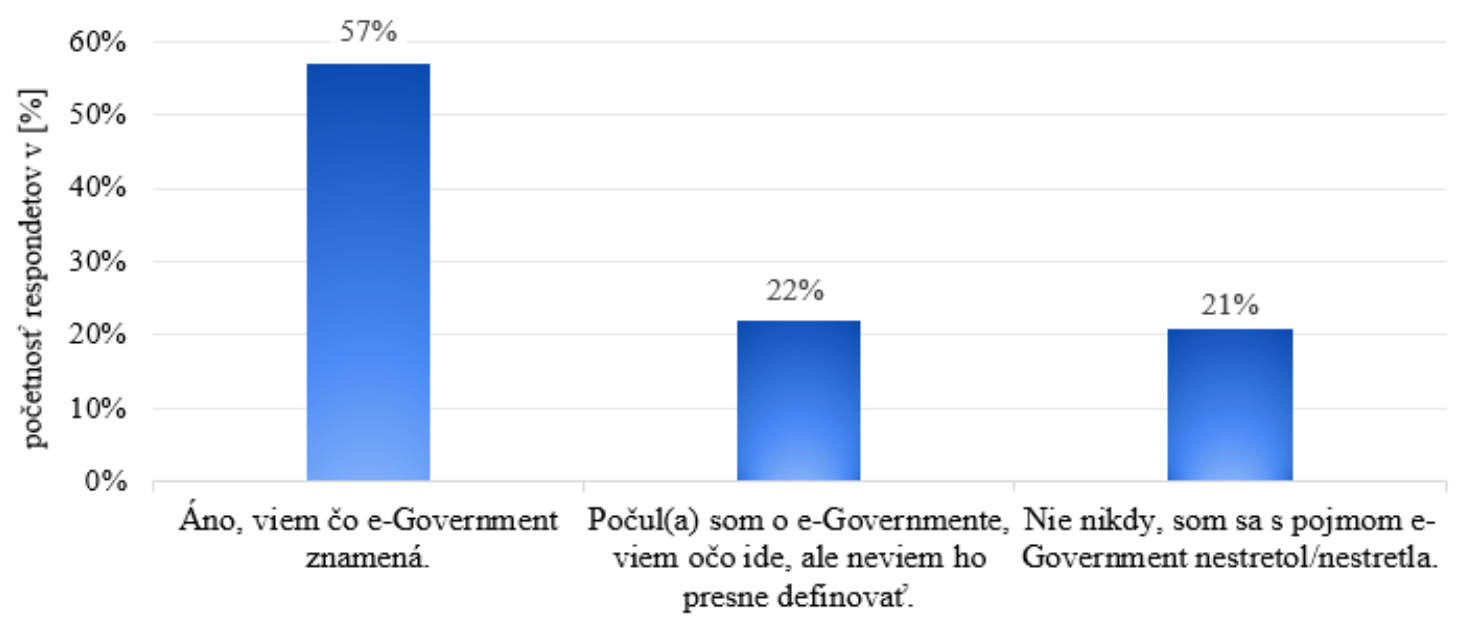

Obrázok 1 Znalost’ pojmu e-Governmentu medzi respondentami.

Zdroj: vlastné spracovanie.

Z výsledkov výskumu je možno konštatovat', že väčšina opýtaných respondentov, až $57 \%$ sa s pojmom e-Government stretla a vedia tento pojem definovat'. Respondenti, ktorí

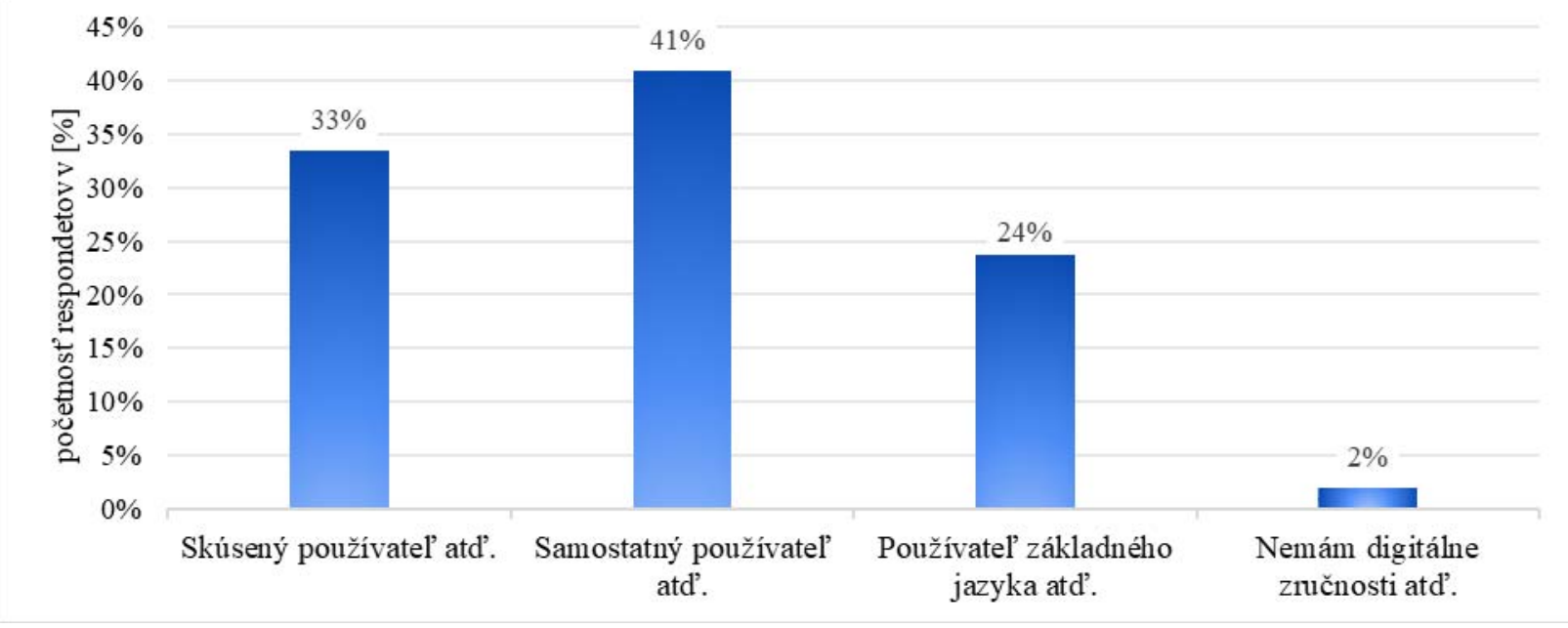

Obrázok 2 Digitálne zručnosti v oblasti komunikácie s VS

Zdroj: vlastné spracovanie.

nevedia, čo e-Government predstavuje je $22 \%$ respondentov. Tieto odpovede je možno vnímat' pozitívne. Posledná odpoved' identifikuje respondentov, ktorí sa s pojmom nestretli, túto možnost' označilo $21 \%$. Aj ked' má vláda medzi prioritami zlepšit' digitálne zručnosti, súčast'ou tejto stratégie by mala byt' aj informovanost' občanov o využívaní elektronických službách štátu.

Digitálne zručnosti v oblasti komunikácie s VS - pozri obrázok 2. Najpočetnejšiu skupinu až $41 \%$ tvoria respondenti, tzv. samostatný používatel'. Druhú najpočetnejšiu skupinu tvorí $33 \%$ respondentov tzv. skúsení používatelia a predposlednú skupinu tvoria respondenti tzv. používatelia základného jazyka, ktorých je $24 \%$ respondentov. Za pozitívne je možné vnímat', že iba $2 \%$ opýtaných respondentov nemajú digitálne zručnosti. Pri podrobnej identifikácii na základe veku vyplýva, že najskúsenejší používatelia sú vo vekovej kategórii od 50 do 59, čo tvorí $53 \%$ respondentov v tejto vekovej kategórii. (Obrázok 3) 
Taktiež je možné konštatovat', že digitálne zručnosti voblasti komunikácie s VS majú najväčšie zastúpenie vo vekových kategóriách od 30 do 59.

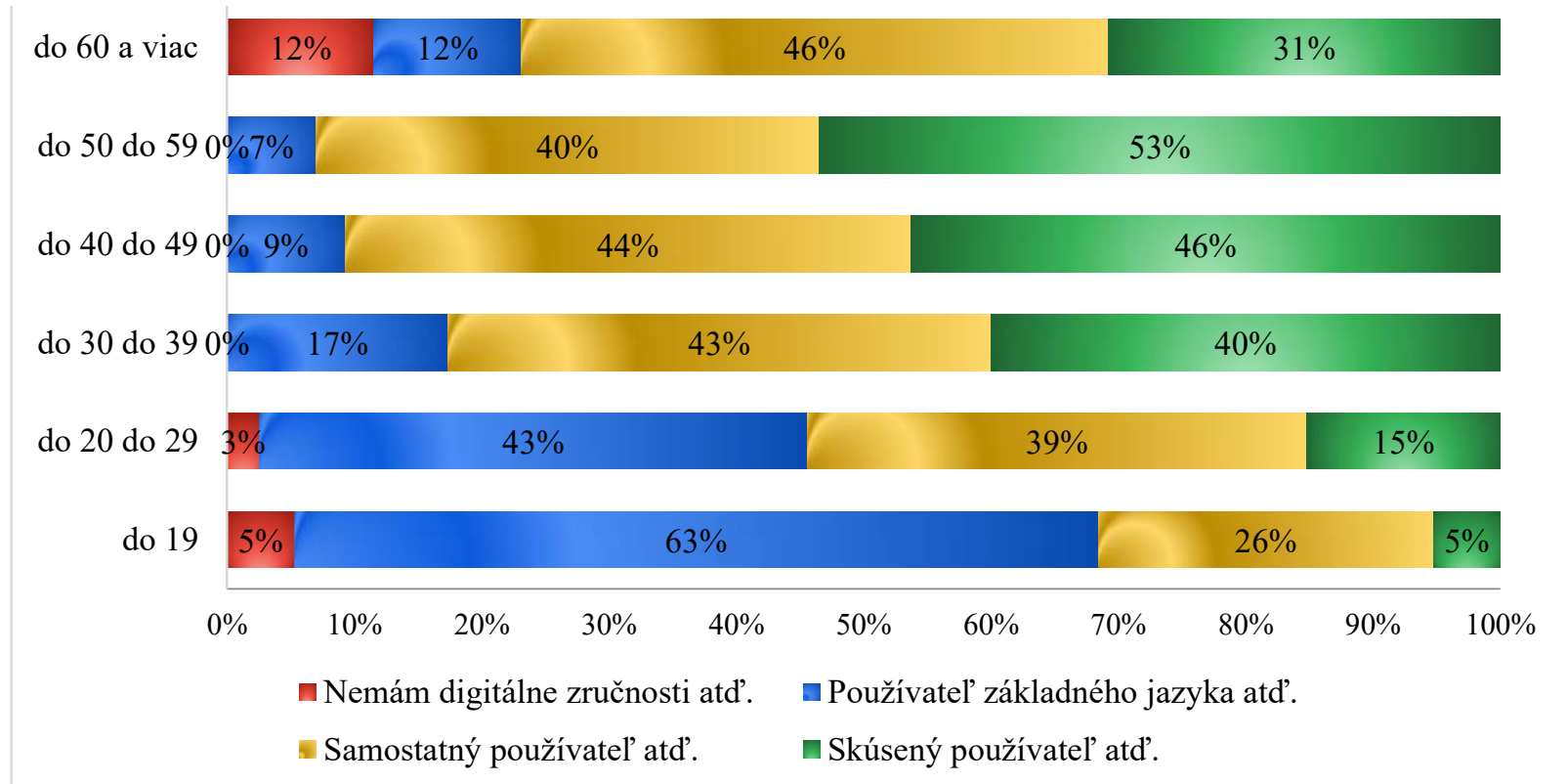

\section{Obrázok 3 Digitálne zručnosti v komunikácii s VS na základe vekovej kategórie}

Zdroj: vlastné spracovanie.

Z prieskumu je možné zhodnotit', že ak respondenti patria do nižšej vekovej kategórie tak, ich digitálne zručnosti sú základne. Inými slovami nepovažujú sa za skúsených alebo samostatných používatel'ov, čo vyplýva aj z analýzy, ktorá identifikuje nutnost' transformácie vzdelávacieho systému. Samostatní používatelia tvoria najväčšie zastúpenie naprieč všetkými kategóriami (študent, zamestnanec, podnikatel').

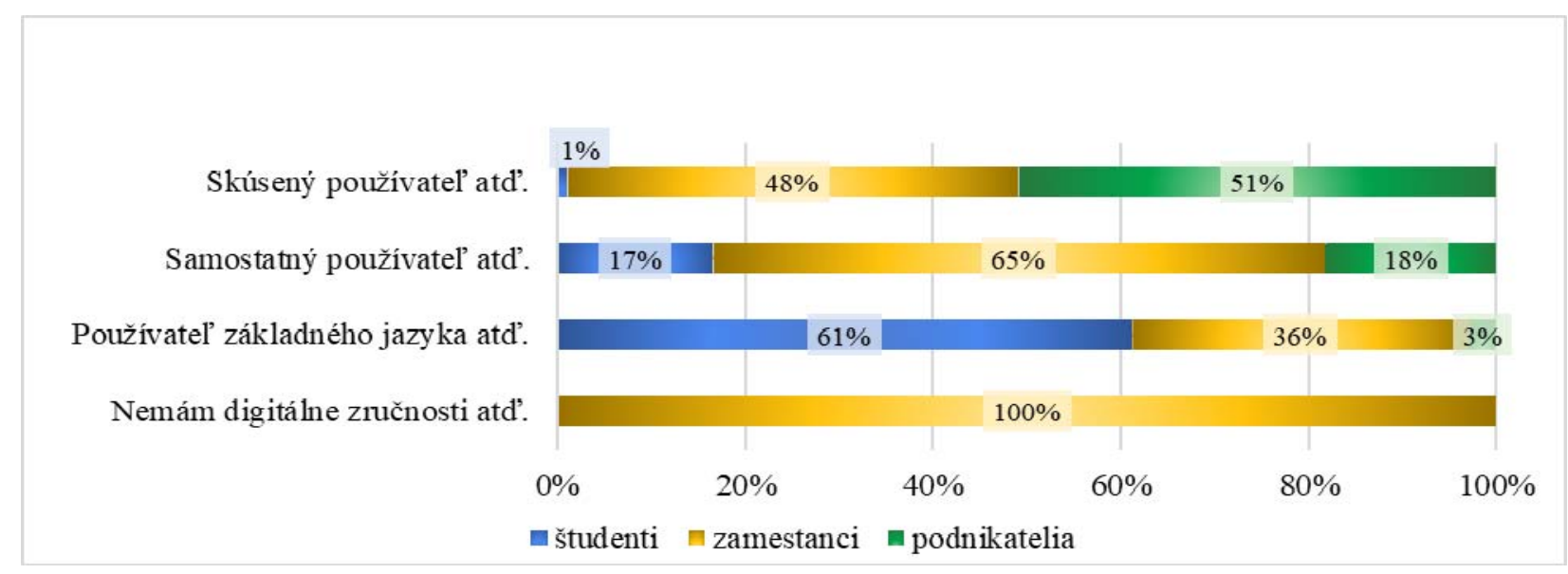

Obrázok 4 Digitálne zručnosti na základe ekonomického zaradenia Zdroj: vlastné spracovanie. 
Z primárneho výskumu je možné konštatovat', že na základe ekonomického zaradenia, ktorými sú študenti, zamestnanci a podnikatelia túto kategóriu tvorí 281 respondentov. Pozitívne je možno zhodnotit', že žiaden študent neoznačil, že nemá digitálne zručnosti a túto možnost' vo vybranej kategórii označili iba zamestnanci, ktorí predstavujú $1,2 \%$ respondentov. Respondenti, ktorí majú základne digitálne zručnosti sú hlavne študenti, a to až $61 \%$ respondentov, túto kategóriu reprezentuje $25,7 \%$ respondentov.

Respondenti, ktorí sa považujú za samostatných používatel'ov, tvoria najväčšiu zastupujúcu vzorku až 38,8 \% z celkového počtu respondentov v tejto kategórii majú najväčšie zastúpenie zamestnanci. Počet študentov s rastúcou úrovňou klesá. Skúsených používatel'ov tvoria podnikatelia a následne zamestnanci, avšak iba o $2 \%$. Tento stav môžeme považovat' za vyvážený. Iba 1 \% študentov označilo možnost' skúsený použivatel'. Čo nám potvrdzuje aj nutnost' zlepšovania digitálnych zručnosti na školách, aby požiadavky zamestnávatel'ov korešpondovali so schopnost’ami a nárokmi na zamestnancov a boli schopní komunikovat's úradmi VS a využívat' služby e-Governmentu.

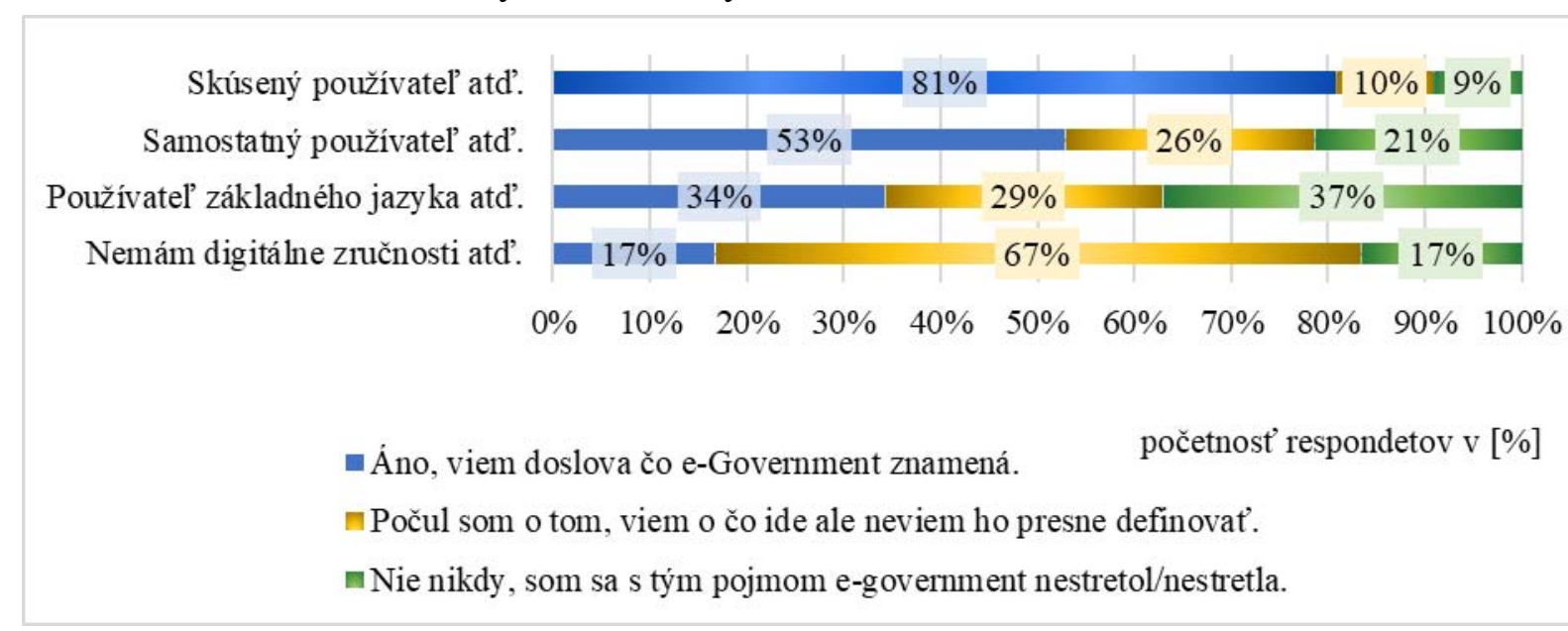

Obrázok 5 Úroveň digitálnych zručnosti k informovanosti o e-Governmente

Zdroj: vlastné spracovanie.

Z výsledkov prieskumu tiež vyplýva, že čím respondent vie definovat' e-Government súčasne sú títo používatelia skúsenejší. Tento stúpajúci trend môžeme vidiet' na obrázku 5. od $17 \%$ respondentov do $81 \%$. Táto skupina respondentov vie definovat' e-Government. Skoro rovnaká inverzia odpovedí platí pri respondentoch, ktorí sa stýmto pojmom nikdy nestretol/nestrela. Môžeme predpokladat', že skúsení používatelia v tejto oblasti nie sú ochotní využívat' služby e-Governmentu a nie sú nútení sa o tomto pojme informovat'.

\section{Záver}

Súčasná kríza prehíbila a ukázala nedostatky v oblasti e-Governmentu. Úroveň digitálnych zručnosti má vplyv na využívanie elektronických služieb. Ciel'om článku bolo poukázat' na digitálne zručnosti obyvatel’ov ŽSK v jednotlivých vybraných kategóriách a tiež oboznámenie sa s e-Governmentom. Z výsledkov realizovaného primárneho prieskumu a vykonanej analýzy vyplýva, že úroveň digitálnych zručnosti je pod priemerom a niektoré vekové kategórie nedisponujú dostatočnými digitálnymi zručnost’ami, aby využívali všetky služby e-Governmentu. Slovenská vláda a príslušné Ministerstvo investícií, regionálneho rozvoja a informatizácie nevytvorilo stratégiu alebo dokument na nasledujúce roky, ktoré by zvyšovalo úroveň digitálnych zručnosti. Za pozitívne možno konštatovat', že zlepšovanie digitálnych zručností patrí medzi priority EÚ a stratégie digitálnej transformácie do 2030. Prijatý akčný plán na roky 2019 - 2022 sa zameriava na rozvoj soft skills. Digitálne zručnosti Slovenskej republiky sa nezvýšili, čo potvrdzuje index DESI, čo spôsobila súčasná kríza. Digitálne zručnosti sú kl'účovým aspektom pre zvyšovanie životnej úrovne občanov, z 
dlhodobého hl'adiska sa investícia do oblasti l'udského kapitálu a zvyšovanie digitálnych zručností môže priniest' benefity pre slovenskú ekonomiku, napríklad vo väčšej odolnosti ekonomiky v časoch krízy alebo pandémia.

\section{Literatúra}

[1] EUROPEAN COMISSION, 2020. Digital Economy and Society Index. Dostupné na: https://ec.europa.eu/newsroom/dae/document.cfm?doc_id=66931

[2] STOFKOVA, Z.; SOLTES, V; STOFKOVA, J. 2019. Survey of the citizens digital skills in the region. 12th Annual International Conference of Education, Research and Innovation. ICERI Proceedings, pp. 7127-7132 .

[3] VICE PREMIER GOV, 2021. Stratégia digitálnej transformácie Slovenska 2030. Dostupné na: https://www.vicepremier.gov.sk/wp-content/uploads/2019/06/Strategiadigitalnej-transformacieSlovenska-2030.pdf.

[4] VICE PREMIER GOV, 2021. Akčný plán digitálnej transformácie Slovenska. Dostupné na: $\quad$ https://www.vicepremier.gov.sk/wp-content/uploads/2019/07/Akcny-planDTS_2019-2022.pdf.

[5] MINISTERSTVO HOSPODÁRSTVA SLOVENSKEJ REPUBLIKY, 2021. Akčný plán inteligentného priemyslu. Dostupné na: https://www.mhsr.sk/inovacie/strategie-apolitiky/akcny-plan-inteligentneho-priemyslu-sr.

[6] MINISTERSTVO ŠKOLSTVA, VEDY, VÝSKUMU A ŠPORTU SLOVENSKEJ REPUBLIKY, 2021. Štátna školská inšpekcia informuje o výsledkoch svojej činnosti. Dostupné na: https://www.minedu.sk/statna-skolska-inspekcia-informuje-o-vysledkochsvojej-cinnosti/.

[7] EUROPEAN COMISSION, 2021. Survey of Schools: ICT in education. Dostupné na: https://ec.europa.eu/digital-single-market/en/news/2nd-survey-schools-ict-education.

[8] DITIALNA KOALICIA, 2021. Záverečná správa z IT fitness testu. Dostupné na: https://digitalnakoalicia.sk/wp-content/uploads/2021/01/IT-Fitness-Zaverecna-Sprava2020.pdf/.

[9] IT AKADEMIA, 2021. Strategický ciel'. Dostupné na: http://itakademia.sk/zakladneinformacie.

[10] MINISTERSTVO ŠKOLSTVA, VEDY, VÝSKUMU A ŠPORTU SLOVENSKEJ REPUBLIKY, 2021. Národný program rozvoja výchovy a vzdelávania. Dostupné na: https://www.minedu.sk/data/att/13285.pdf.

[11] DIGITALNA KOALÍCIA, 2021. Digitálna koalícia o nás. Dostupné na: https://digitalnakoalicia.sk/o-nas/.

[12]ŽILINSKÝ SAMOSPRÁVNY KRAJ, 2021. Základné informácie. Dostupné na internete: http://www.zilinskazupa.sk/sk/prave-menu/zilinsky-samospravny-kraj/zakladneinformacie/.

\section{Grantová podpora}

Príspevok bol spracovaný v rámci riešenia projektu KEGA 043ŽU-4/2019 a KEGA 052ŽU4/2021. 